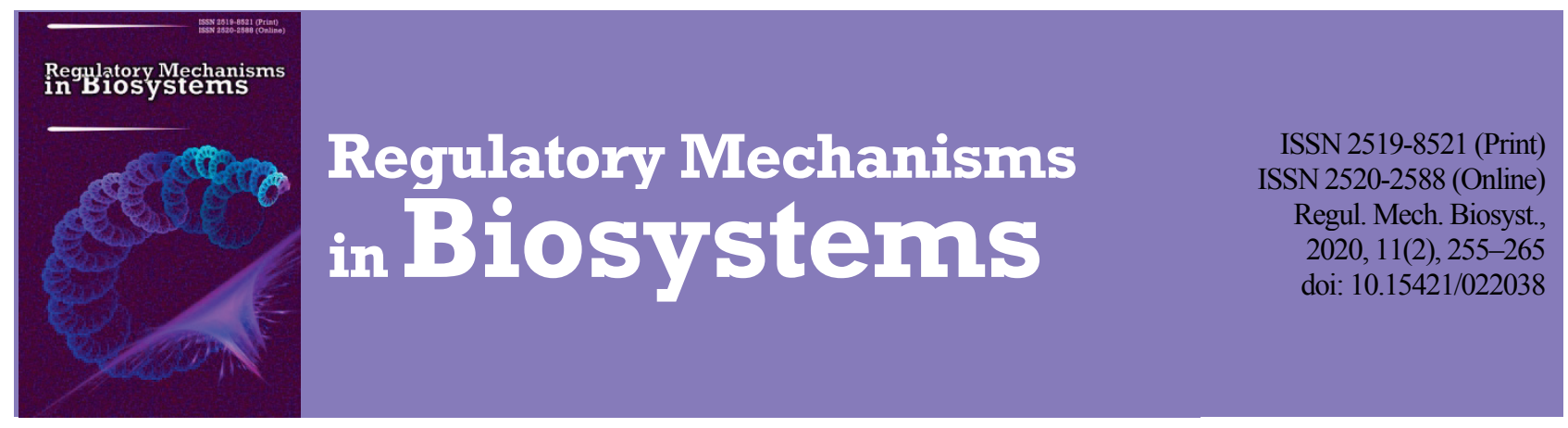

\title{
Modeling of asymmetric division of somatic cell in protoplasts culture of higher plants
}

\author{
S. I. Kondratenko*, T. P. Pasternak**, O. P. Samovol*, O. M. Mogilna*, O. V. Sergienko* \\ *Institute of Vegetables and Melon Growing of National Academy of Agricultural Sciences of Ukraine, Kharkiv region, Uktaine \\ **Albert-Ludwigs-University Freiburg, Freiburg, Germany
}

Article info

Received 16.04.2020

Received in revised form

10.05.2020

Accepted 11.05.2020

Institute of Vegetables and Melon Growing

of National Academy of Agricultural Sciences

of Ukraine, Institutskaya st.,

Selektsiyne village,

Kharkiv region,

62478, Ukraine.

Tel: $+38-057-748-91-91$.

E-mail:

ovoch.iob@gmail.com

Albert-Ludwigs-University.

Schänzle st., 1, Freiburg,

D-79104, Germany.

Tel: +49-157-861-83-538.

E-mail:

taras.p.pasternak@gmail.com

Kondratenko, S. I., Pasternak, T. P., Samovol, O. P., Mogilna, O. M., \& Sergienko, O. V. (2020). Modeling of asymmetric division of somatic cell in protoplasts culture of higher plants. Regulatory Mechanisms in Biosystems, 11(2), $255-265$. doi:10.15421/022038

The key result of the work is the selection of factors for the cultivation of protoplasts of higher plants in vitro, which allowed induction of asymmetrical cell division during the first cell cycle phase. Gibberellin has been proved to be one of the main cofactors of asymmetric division of plant cells. The objects of research were plants of the following cultivars aseptically grown in hormone-free MS medium: tobacco (Nicotiana tabacum L.), SR-1 line; Arabidopsis thaliana var. columbia (L.) Heynh; potato (Solanum tuberosum L.), Zarevo cultivar; cultivated white head cabbage (Brassica oleraceae var. capitata L.) of the following varieties: Kharkivska zymnia, Ukrainska osin, Yaroslavna, Lika, Lesya, Bilosnizhka, Dithmarscher Früher, Iyunskarannya; rape (Brassica napus L.) of Shpat cultivar; winter radish (Raphanus sativus L.) of Odessa-5 cultivar. In experiments with mesophilic and hypocotyl protoplasts of the above-mentioned plant species it has been proved that short-term osmotic stress within 16-18 hours being combined with subsequent introduction of high doses of gibberellin GK3 $(1 \mathrm{mg} / \mathrm{L})$ into the modified liquid nutrient media TM and SW led to the occurrence of pronounced morphological traits of cytodifferentiation already at the initial stages of the development of mitotically active cells in a number of higher plants. Meanwhile, in all analyzed species, there was observed the division of the initial genetically homogeneous population of mitotically active cells into two types of asymmetric division: by the type of division of the mother cell into smaller daughter cells and by the type of the first asymmetric division of the zygotic embryo in planta. In this case, the first type of asymmetric division occurred during unusual cytomorphism of the mother cells: a pronounced heart-shaped form even before the first division, which is inherent in the morphology of somatic plant embryo in vitro at the heart-shaped stage. A particular study of the effect of osmotic stress influencing protoplasts of various cultivars of white cabbage, isolated from hypocotyls of 7-9 day etiolated seedlings, revealed quite a typical consistent pattern: the acquisition and maintenance of the axis of symmetry in growing microcolonies occurred without extra exogenous gibberellin (GK3), which was added to the nutrient medium earlier. While analyzing the effect of growth regulators on the formation of microcolonies with traits of structural organization, the conclusion was made regarding the commonality of the revealed morphogenetic reactions of cells within the culture of protoplasts of higher plants in vitro with similar reactions studied earlier on other plants, both in vitro and in planta. Modeling of asymmetric cell division in protoplast culture in vitro has become possible by carrying out a balanced selection of growth regulators as well as their coordinated application through time along with changes in osmotic pressure of a nutrient medium.

Keywords: plant cell; osmotic stress; first asymmetric division; gibberellic acid (GA3); cell microcolony.

\section{Introduction}

One of the main problems in the framework of plant morphogenesis is the elucidation of the nature of the processes causing polarization and further differentiation of cells (Medvedev, 1996). Such processes include non-equivalent or asymmetric division of the mother cell, which leads to the occurrence of daughter cells of different functions, thereby the primary formation and further maintenance of the axial symmetry of multicellular structures of the plant body.

Bipolar growth is an essential trait of life activity of most plants. Essentially, the plant stem increases upwards, while the root downwards, deepening into the soil. Bipolar growth is primarily due to an increase in a number of cells through reproduction (proliferation) in special cellular structures: apical meristem located at the very top of the stem and at the root tip. In nature, plants are represented by a great variety of life forms, which are widely different in their growth features (Flindt, 1992): the number of cells in the cell chains from the tip of the shoot to the root tip, the ratio of shoot-to-root size, growth rate as well. It is determined that two hormones - auxin and cytokinin - are necessary for the separation of plant cells (Dante et al., 2014). It is essential that these phytohormones are synthesized mainly at the plant poles: auxin is being synthesized at the crown of the stem and cytokinin - at the root apex. Through transport channels, the auxin in plants moves downward, while the cytokinins move towards them (Polevoj, 1982; Polevoj \& Salamatova, 1991). The role of hormonal counterflow within the organization of growth processes is still not fully clarified. So far, it has not been possible to experimentally identify the auxin-cytokinin counterflow circuit or study its functions as a plant growth inductor. To solve this problem, it is considered quite effective to apply different kinds of simulation. In particular, the authors of one of the published works proposed a mathematical model in which the bihormonal contour controls the proliferative growth of a plant-type cell structure (Sukhoverov \& Romanov, 2009).

In plants, the patterns of cell division in combination with growth and differentiation determine the hierarchical organization of plant tissues and organs. Cells can reproduce using symmetrical divisions, while asymmetrical ones are mainly related to the initiation of new cell types, neoplasms 
and development patterns (Rasmussen et al., 2011; Smolarkiewicz \& Dhonukshehe, 2013). In asymmetric division, the formation of the cleavage plane is often associated with cell polarity. The common paradigm is that the position of the cleavage plane will be determined by such an asymmetrically distributed determinant that will lead daughter cells to different directions of development. An alternative view is that daughter cells will initially have the same determinant, however, they will be exposed to different positional signals that will cause them to develop in various manners (Horvitz \& Herskowitz, 1992). Therefore, elucidating the principles that govern symmetric and asymmetric divisions provides for better understanding the cellular bases of plant development as well as plant morphogenesis in general. The early embryogenesis of Arabidopsis thaliana has been deemed to be an attractive model for studying how the positions and orientation of cleavage planes are being selected. During the first generations of cells, exclusive embryo geometry is indeed organized from a single initial cell through a stereotype sequence of invariant oriented cell divisions (Mansfield \& Briarty, 1991; Capron et al., 2009). Thus, the boundaries of the future direction of cell division have been established and mapped using numerous genetic and cytological reverse analyses, and these properties have been successfully used to identify the origin of developmental defects in mutant patterns (Laux et al., 2004; Palovaara et al., 2016). The influence of cell shape on the orientation and choice of cleavage planes in animal and plant cells has attracted much attention (Minc \& Piel, 2012) with special emphasis on the common rules of cleavage defined as early as the late XIX century (Errera, 1888). According to the Errera rule (Errera, 1888), plant cells will behave as soap bubbles, so that symmetrical separations will adhere to the principle of minimum surface area. Besson \& Dumais (2011) recently rearranged the rule in a stochastic version, according to which the choice of the cleavage plane between the various alternatives depending on the distribution of probabilities is associated with the plane area. It is generally accepted that the principle of minimizing surface area, according to the Errera rule, will a priori be a mechanism for separating plant cells in the absence of internal or external traits (Roeder, 2012). However, the vast majority of studies supporting this view have focused on symmetrical divisions in tissues that have been assimilated in 2D systems (e.g., tissues with a constant cell layer and absolutely anticlinical divisions). The question of whether geometric rules are acceptable of describing a 3D division of plant cells deserves to be asked. Recently, Yoshida et al. (2014) reported, however, that they were unable to identify the geometric rule, which underlies the sequence of 3D cell division models in the Arabidopsis thaliana zygotic embryos.

Other authors (Moukhtar et al., 2019) questioned the existence and nature of the rules governing cell division during early zygote embryos' stage. Using automatic image analysis of 3D embryos, they quantitatively determined cell shapes and models of cell division. It was found out that the distance between the equator of a cell and the mother cell's centroid was an invariant trait of the generations' course and spatial boundaries. Being based on the developed computer cell division model, the authors (Moukhtar et al., 2019) investigated the space of possible division planes under geometric constraints in real three-dimensional cell forms. On the basis of the proposed model, a new rule for predicting the position and orientation of division planes by the geometry of the mother cell was established, which was true for both symmetric and asymmetric cell division. The results supported the key role of the geometric feedback loop between the cell shape and the position within the cleavage plane in the self-organization of the early embryo.

The above-mentioned instances of asymmetric cell division, as well as variants of mathematical modeling of this type of division were considered on plant objects with pre-genetically determined development program at the in planta level, i.e. the modeling concerned those cases when the course of cytodifferential cell division were under genetic and regulatory control of a plant body.

In this regard, the culture of isolated protoplasts of higher plants in vitro can serve as an alternative model system for identifying and studying the cofactors of cytodifferential division and growth of plant cells as well. The feature of this model system is that it allows one to investigate the cofactor role of growth regulators as well as elements of osmotic and trophic regulation of cell division of isolated somatic plant cells in vitro (Butenko, 1981; Kuchuk, 2017).
In experiments with tobacco culture it was shown (Nawaga et al., 1987) that the identification of endogenous gibberellin is closely correlated with the onset of morphogenesis. The results of embryological studies on all plant species concerned also demonstrate the direct involvement of endogenous gibberellins in the formation of zygotic embryos in planta, beginning with the heart-shaped development stage (Trigiano et al., 1987). However, in a number of already prepared studies, the physiological effect of the phytohormone was evaluated on multicellular structures, confirming a failure to fully manifest its functions. A rather convenient object for study is the culture of isolated protoplasts, where a mitotically active somatic cell may be a potential morphogenetic unit. Therefore, this cell type is an ideal experimental object for simulating different types of morphogenesis in culture in vitro. The purpose of our research was to determine the informative possibilities of the culture of protoplasts of higher plants in vitro as a model system capable of reproducing asymmetric division of somatic plant cells only due to the action of exogenous factors of growth and development controlled by a researcher.

\section{Materials and methods}

Six plant species from the Brassicaceae and Solanaceae families were chosen as research objects, which in the culture of protoplasts during gradual application of nutrient media TMmod1 (k), TMmod2 (k) and TMmod3 (k) and SWmod1 (k), SWmod2 (k) and SWmod3 (k) (Table 1) initiated the first symmetrical divisions of the cells, from which the unorganized growing colonies were then formed. The following tube stock plants were aseptically grown in vitro on hormone-free agarized MS medium (Murashige \& Skoog, 1962): SR-1 line of tobacco (Nicotiana tabacum L.) (Maliga et al., 1973); wild species of Arabidopsis (A. thaliana var. colymbia (L.) Heynh.); Zarevo variety of potato (Solanum tuberosum L.); whitehead cabbage (Brassica oleraceae var. capitata L.) varieties: Kharkivska zymova, Ukrainska osin, Yaroslavna, Lika, Lesia, Bilosnizhka, Dithmarscher Früher and Iuinskarannia; Shpat variety of rape (Brassica napus L.); Odeska-5 variety of winter radish (Raphanus sativus L.).

Protoplasts of leaf mesophyll were extracted from microclonal propagated juvenile plants, with well-developed leaf area. Hypocotyl protoplasts were excreted from ethylated seedlings for 7-9 days of cultivation. Leaf or hypocotyl tissues were cut into strips $1 \mathrm{~mm}$ wide and incubated under darkroom conditions at $28{ }^{\circ} \mathrm{C}$ for $16-18$ hours in an enzymatic solution containing $0.5 \%$ Macerozyme ("Calbiochem", USA), $0.5 \%$ Onozuka R10 ("Jacult Biochemicals", Japan), $0.5 \mathrm{M}$ sucrose and $5 \mathrm{mM} \mathrm{CaCl}$ (pH 5.6). The isolated protoplasts were separated from residual tissue through metal filters with a pore diameter of $64 \mu \mathrm{m}$. The filtrate was transferred to centrifuge tubes $(10 \mathrm{~mL})$ and then centrifuged at $700 \mathrm{rpm}$ for $7 \mathrm{~min}$. The ring of floated protoplasts was selected by a Pasteur pipette and washed at least twice in a W-5 medium (Medgyesy et al., 1980), precipitating them each time by centrifugation for 5 minutes at $700 \mathrm{rpm}$. The number of protoplasts in the medium was calculated using the Goriaiev chamber.

In our studies, the addition of exogenous gibberellin (GK3) to the composition of nutrient medium growth regulators proved to be effective, starting from the first mitotic cell division in protoplast culture and at growth of microcolonies formed after the 5th and 6th mitosis. After tissue fermentation and isolation procedure (Sidorov et al., 1985), protoplasts of various plant varieties within the experimental variant of cultivation were transferred to the appropriate nutrient media SWmod1 (d) and Tmod1 (d) (Table 1) and cultivated on diffuse light at $22-24{ }^{\circ} \mathrm{C}$ for $16-18$ hours under stress (hypotonic) conditions $(0.36 \mathrm{M}$ glucose) with a population of $10^{4}-10^{5}$ cells $/ \mathrm{mL}$. Then the level of osmotic agents was brought to $0.5 \mathrm{M}$ (modifications of SWmod2 (d) and Tmod2 (d), respectively). The increase in osmotic concentration was followed by simultaneous injection of exogenous gibberellin (1 mg/L GK3) into nutrient medium. Further, the level of osmotic agents was brought up to $0.5 \mathrm{M}$ (modifications) during the first 48 hours of cultivation, more than $80 \%$ of both mesophilic and hypocotyl protoplasts of the studied plant cultivars were fully restored to the cellular membrane. The morphological criterion for such a condition in cultured protoplasts was a change in their spherical shape to elongated or oval, which is typical for suspension-cultured cells (Fig. 1). The identification of regenerating cell membranes in protoplasts was carried out by colouring them with $0.01 \%$ calcofluor (Calcofluor white, MR-2, "Serva") 
on $0.1 \mathrm{M}$ phosphate buffer, $\mathrm{pH} 7.2$ during 5-10 minutes following the Herth method (Herth \& Schnepf, 1980). For this purpose, microdrops of cell suspensions of 10-20 $\mu \mathrm{L}$ were used, which were selected from the nutrient media. Having being washed with a buffer, protoplasts were exa- mined with the help of a fluorescent microscope ML-2, the luminescence was caused by the blue light of a mercury lamp and a light blue-green glass filter. Calculation of the percentage of protoplasts from regenerated membranes was carried out for 24 hours and 48 hours of cultivation.

Table 1

The composition of liquid nutrient media $(\mathrm{mg} / \mathrm{L})$ for cultivation of protoplasts of higher plants in the experimental (e) and control (c) variants

\begin{tabular}{|c|c|c|c|c|c|c|c|c|c|c|c|c|}
\hline \multirow[b]{2}{*}{ Components * } & \multicolumn{12}{|c|}{ The content in nutrient medium, $\mathrm{mg} / \mathrm{L}$} \\
\hline & $\begin{array}{c}\text { TMmod1 } \\
(\mathrm{e})\end{array}$ & $\begin{array}{c}\text { TMmod1 } \\
\text { (c) }\end{array}$ & $\begin{array}{c}\text { TMmod2 } \\
\text { (e) }\end{array}$ & $\begin{array}{c}\text { TMmod2 } \\
(\mathrm{c})\end{array}$ & $\begin{array}{c}\text { TMmod3 } \\
(\mathrm{e})\end{array}$ & $\begin{array}{c}\text { TMmod3 } \\
\text { (c) }\end{array}$ & $\begin{array}{c}\text { SWmod1 } \\
(\mathrm{e})\end{array}$ & $\begin{array}{l}\text { SWmodl } \\
\text { (c) }\end{array}$ & $\begin{array}{c}\text { SWmod2 } \\
(\mathrm{e})\end{array}$ & $\begin{array}{l}\text { SWmod2 } \\
\text { (c) }\end{array}$ & $\begin{array}{l}\text { SWmod3 } \\
\text { (e) }\end{array}$ & $\begin{array}{c}\text { SWmod3 } \\
\text { (c) }\end{array}$ \\
\hline \multicolumn{13}{|l|}{ Macronutrients: } \\
\hline $\mathrm{NH}_{4} \mathrm{Cl}$ & 0.0 & 0.0 & 0.0 & 0.0 & 0.0 & 0,0 & 133.0 & 133.0 & 133.0 & 133.0 & 133.0 & 133.0 \\
\hline $\mathrm{NH}_{4} \mathrm{NO}_{3}$ & 200.0 & 200.0 & 200.0 & 200.0 & 200.0 & 200.0 & 0.0 & 0.0 & 0.0 & 0.0 & 0.0 & 0.0 \\
\hline $\mathrm{KNO}_{3}$ & 1500.0 & 1500.0 & 1500.0 & 1500.0 & 1500.0 & 1500.0 & 1900.0 & 1900.0 & 1900.0 & 1900.0 & 1900.0 & 1900.0 \\
\hline $\mathrm{CaCl}_{2} \times 2 \mathrm{H}_{2} \mathrm{O}$ & 440.0 & 440.0 & 440.0 & 440.0 & 440.0 & 440.0 & 440.0 & 440.0 & 440.0 & 440.0 & 440.0 & 440.0 \\
\hline $\mathrm{MgSO}_{4} \times 7 \mathrm{H}_{2} \mathrm{O}$ & 370.0 & 370.0 & 370.0 & 370.0 & 370.0 & 370.0 & 370.0 & 370.0 & 370.0 & 370.0 & 370.0 & 370.0 \\
\hline $\mathrm{KH}_{2} \mathrm{PO}_{4}$ & 170.0 & 170.0 & 170.0 & 170.0 & 170.0 & 170.0 & 170.0 & 170.0 & 170.0 & 170.0 & 170.0 & 170.0 \\
\hline \multicolumn{13}{|l|}{ Fe-helate: } \\
\hline $\mathrm{Na}_{2}$ EDTA & 37.3 & 37.3 & 37.3 & 37.3 & 37.3 & 37.3 & 37.3 & 37.3 & 37.3 & 37.3 & 37.3 & 37.3 \\
\hline $\mathrm{FeSO}_{4} \times 7 \mathrm{H}_{2} \mathrm{O}$ & 27.8 & 27.8 & 27.8 & 27.8 & 27.8 & 27.8 & 27.8 & 27.8 & 27.8 & 27.8 & 27.8 & 27.8 \\
\hline \multicolumn{13}{|l|}{ Micronutrients: } \\
\hline $\mathrm{H}_{3} \mathrm{BO}_{3}$ & 3.0 & 3.0 & 3.0 & 3.0 & 3.0 & 3.0 & 3.0 & 3.0 & 3.0 & 3.0 & 3.0 & 3.0 \\
\hline $\mathrm{MnSO}_{4} \times 5 \mathrm{H}_{2} \mathrm{O}$ & 13.2 & 13.2 & 13.2 & 13.2 & 13.2 & 13.2 & 13.2 & 13.2 & 13.2 & 13.2 & 13.2 & 13.2 \\
\hline $\mathrm{ZnSO}_{4} \times 7 \mathrm{H}_{2} \mathrm{O}$ & 2.0 & 2.0 & 2.0 & 2.0 & 2.0 & 2.0 & 2.0 & 2.0 & 2.0 & 2.0 & 2.0 & 2.0 \\
\hline $\mathrm{NaMoO}$ & 0.25 & 0.25 & 0.25 & 0.25 & 0.25 & 0.25 & 0.25 & 0.25 & 0.25 & 0.25 & 0.25 & 0.25 \\
\hline $\mathrm{KJ}$ & 0.75 & 0.75 & 0.75 & 0.75 & 0.75 & 0.75 & 0.75 & 0.75 & 0.75 & 0.75 & 0.75 & 0.75 \\
\hline $\mathrm{CoSO}_{4} \times 6 \mathrm{H}_{2} \mathrm{O}$ & 0.025 & 0.025 & 0.025 & 0.025 & 0.025 & 0.025 & 0.025 & 0.025 & 0.025 & 0.025 & 0.025 & 0.025 \\
\hline $\mathrm{CuSO}_{4} \times 5 \mathrm{H}_{2} \mathrm{O}$ & 0.025 & 0.025 & 0.025 & 0.025 & 0.025 & 0.025 & 0.025 & 0.025 & 0.025 & 0.025 & 0.025 & 0.025 \\
\hline \multicolumn{13}{|l|}{$\begin{array}{c}\text { Vitamins and other biologically } \\
\text { active components: }\end{array}$} \\
\hline Mesoinositol & 100.0 & 100.0 & 100.0 & 100.0 & 100.0 & 100.0 & 100.0 & 100.0 & 100.0 & 100.0 & 100.0 & 100.0 \\
\hline $\mathrm{B}_{1}$ & 10.0 & 10.0 & 10.0 & 10.0 & 10.0 & 10.0 & 10.0 & 10.0 & 10.0 & 10.0 & 10.0 & 10.0 \\
\hline $\mathrm{B}_{6}$ & 1.0 & 1.0 & 1.0 & 1.0 & 1.0 & 1.0 & 1.0 & 1.0 & 1.0 & 1.0 & 1.0 & 1.0 \\
\hline PP & 1.0 & 1.0 & 1.0 & 1.0 & 1.0 & 1.0 & 1.0 & 1.0 & 1.0 & 1.0 & 1.0 & 1.0 \\
\hline Casein hydrolyzate & 150.0 & 150.0 & 150.0 & 150.0 & 150.0 & 150.0 & 150.0 & 150.0 & 150.0 & 150.0 & 150.0 & 150.0 \\
\hline \multicolumn{13}{|l|}{ Growth regulators: } \\
\hline $\mathrm{BAP}(6$ & 0.5 & 0.5 & 0.5 & 0.5 & 1.0 & 1.0 & 0.5 & 0.5 & 0.5 & 0.5 & 1.0 & 1.0 \\
\hline NAA ( $\alpha$-naphthyl & 1.0 & 1.0 & 0.1 & 0.1 & 0.1 & 0.1 & 2.0 & 2.0 & 0.1 & 0.1 & 0.1 & 0.1 \\
\hline 2,4-D (2,4-dichlo & 0.2 & 0.2 & 0.2 & 0.2 & 0.2 & 0.2 & 0.2 & 0.2 & 0.2 & 0.2 & 0.2 & 0.2 \\
\hline $\mathrm{GA}_{3}$ (gibberellic acid) & 0.0 & 0.0 & 1.0 & 0.0 & 1.0 & 0.0 & 0.0 & 0.0 & 1.0 & 0.0 & 1.0 & 0.0 \\
\hline \multicolumn{13}{|l|}{ Carbohydrate sources (osmotic agents): } \\
\hline Glucose & 64870.0 & 90100.0 & 90100.0 & 90100.0 & 72000.0 & 72000.0 & 64870.0 & 90100.0 & 90100.0 & 90100.0 & 72000.0 & 72000.0 \\
\hline centration) & 36M) & $(0.5 \mathrm{M})$ & $(0.5 \mathrm{M})$ & $(0.5 \mathrm{M})$ & $(0.4 \mathrm{M})$ & $(0.4 \mathrm{M})$ & $(0.36 \mathrm{M}$ & $(0.5 \mathrm{M})$ & $(0.5 \mathrm{M})$ & $(0.5 \mathrm{M})$ & $(0.4 \mathrm{M})$ & $(0.4 \mathrm{M})$ \\
\hline Xylose & 125.0 & 125.0 & 125.0 & 125.0 & 125.0 & 125.0 & 125.0 & 125.0 & 125.0 & 125.0 & 125.0 & 125.0 \\
\hline The level of acidity of nutrient $m$ & 5.8 & 5.8 & 5.8 & 5.8 & 5.8 & 5.8 & 5.8 & 5.8 & \begin{tabular}{|l}
5.8 \\
\end{tabular} & 5.8 & 5.8 & 5.8 \\
\hline
\end{tabular}

Note: * - experimental nutrient media for white head cabbage, rapeseed and radish protoplasts - TMmod1(e) for cultivation of protoplasts under conditions of hypotonic stress $(0.36 \mathrm{M}$ glucose) $\mathrm{TMmod} 2$ (e) for the cultivation of protoplasts after the first division (at the optimum for the initiation of mitotic activity of the osmotic content $0.5 \mathrm{M}$ glucose) and simultaneous removal of osmotic stress, TMmod3(e)-for culturing cells at a later stage in the formation of micro colonies; similarly intended nutrient media for protoplasts of tobacco, potatoes and Arabidopsis - SWmod1(e), SWmod2(e), SWmod3(e).

Within 60-72 hours after about $50 \%$ of cells started the first cell division, the suspensions were diluted with liquid media TMmod3 (d) and SWmod3 (d) with a low auxin content $(0.1 \mathrm{mg} / \mathrm{L}$ NAA) and a high one of gibberellin $(1 \mathrm{mg} / \mathrm{L} \mathrm{GK} 3)$ in order to reach the final density of $10^{2}-10^{3}$ cells $/ \mathrm{mL}$. Phenological observations of the state of culture were carried out on a daily basis, while the number of formed microcolonies from one mitotic active cell and their morphological analysis for 15 days of cultivation were counted. The registration of the state of cell as well as microcolony development in vitro cultures of mesophilic and hypocotyl protoplasts of various plant varieties was carried out within two months - a sufficient period at which in the applied experimental option of cell cultivation the traits of structural organization of microcolonies and their complete transition to unorganized growth were completely lost. During the first 20 days, cell culture was grown in the darkroom conditions, then transferred to diffuse light to gradually grow the existing callus clones to an optimum size of 3-4 mm in diameter, which is necessary for their migration to agarized nutrient media. Photo fixing of various stages of growth and division of floating cells in nutrient media of protoplasts and plant cells after the cellular membrane and microcolonies repair process was carried out by photographing them on black and white film with the use of a Zenith camera from the photonhead to an inverted microscope of the Olympus CKX53. The mitotic activity of cells in protoplast culture was assessed by fixation of callus and cell aggregates in a mixture of ethanol-acetic acid-chloroform $(6: 1: 3)$. The material was dyed in $1 \%$ aceto-orcein and cells at different stages of mitosis were counted under a microscope on squash material. The mitotic index was determined in 5fold repetition when analyzing 5-7 thousand cells for each fixation point. The above cytological parameter was determined using the following formula:

$$
\text { Mitotic index }=\quad \frac{100 \% * \sum \text { of cells at mitosis stage }}{\sum \text { of cells in total }}
$$

The analysis of the experimental data was carried out using the ANOVA method. The differences between the values in the different variants of experience in the cultivation of somatic cells of plants were determined using the Tukey criterion, where the differences were considered reliable at $\mathrm{P}<0.05$ (with consideration of the Bonferroni correction). The numerical data in the tables are presented as $\mathrm{x} \pm \mathrm{SD}(\mathrm{n}=5)$.

\section{Results}

When using the control variant of cultivation of mesophilic protoplasts - a combination of initial isosmotic conditions $(0.5 \mathrm{M}$ glucose $)$ and high doses of auxin ( $1 \mathrm{mg} / \mathrm{L}$ NAA for Brassicaceae plants and $2 \mathrm{mg} / \mathrm{L}$ for Solanaceae), we observed, primarily, the initiation of symmetrical division of daughter cells and further formation of mini-clones in the majority of cases (Fig. 1). Application of low osmotic pressure of the nutrient medium 
during the first 16-18 hours of cultivation led to changes in the morphology of the protoplasts even before full reparation of the cell wall. Namely, under such conditions of cultivation, physiological reaction to osmotic stress (OS) represented excessive vacuolization of protoplasts with formation of large vacuole, which polarized cell cytoplasm (Fig. 2a). Subsequently, a similar cytomorphosis persisted until the beginning of the mitotic activity of the cells and led to the initiation of the first asymmetric divisions with the appearance of daughter cells with clearly visible cytoplasmic optical density - transparent with excessive vacuolization and dense, saturated with cytoplasmic elements (Fig. 2b). Previously, when conducting methodological studies in order to select optimal concentrations of the auxin regulator NAA, we observed the phenomenon of vacuolization in the culture of higher plant protoplasts at the regulator's doses exceeding $2 \mathrm{mg} / \mathrm{L}$ and the initial isosmotic conditions. However, the prolonged exposure to the mentioned dose of auxin only increased the growth of cells by
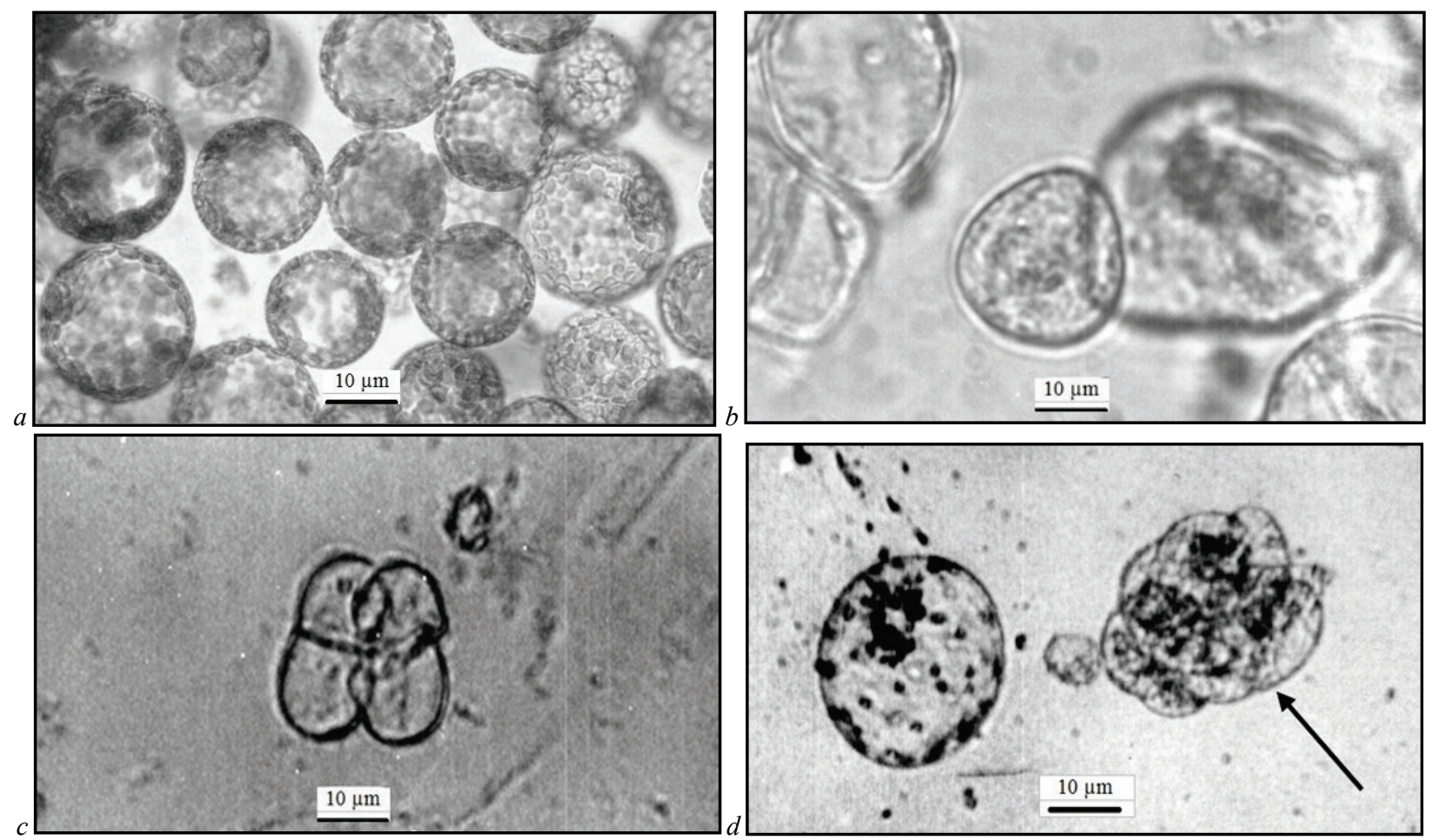

Fig. 1. Typical cell growth in the culture of protoplasts of the studied plant species in vitro under the control variant of cultivation: $a$-recently isolated mesophilic protoplasts of rapeseed Shpat (Brassica napus L.), sown in a liquid nutrient medium TMmod1 (k) $(1 \mathrm{mg} / \mathrm{L} \mathrm{NAA}$; $0.2 \mathrm{mg} / \mathrm{L} 2.4-\mathrm{D}, 0.5 \mathrm{mg} / \mathrm{L} \mathrm{BAP}, 0.5 \mathrm{M}$ glucose); $b$ - cell wall repair process within the first 48 hours of cultivation of hypocotyl protoplasts of white cabbage Kharkivska zymnia (Brassica oleraceae var. capitata L.); $c$ - the first symmetrical cell division of the mother cell (hypocotyl protoplasts of white cabbage Lika cultivar (Brassica oleraceae var. capitata L.)); $d$ - unorganized microcolony growth (highlighted with an arrow) on the nutrient media SWmod3 $(\mathrm{k})$ in the culture of mesophilic tobacco protoplasts in vitro of the SR-1 line (Nicotiana tabacum L.)
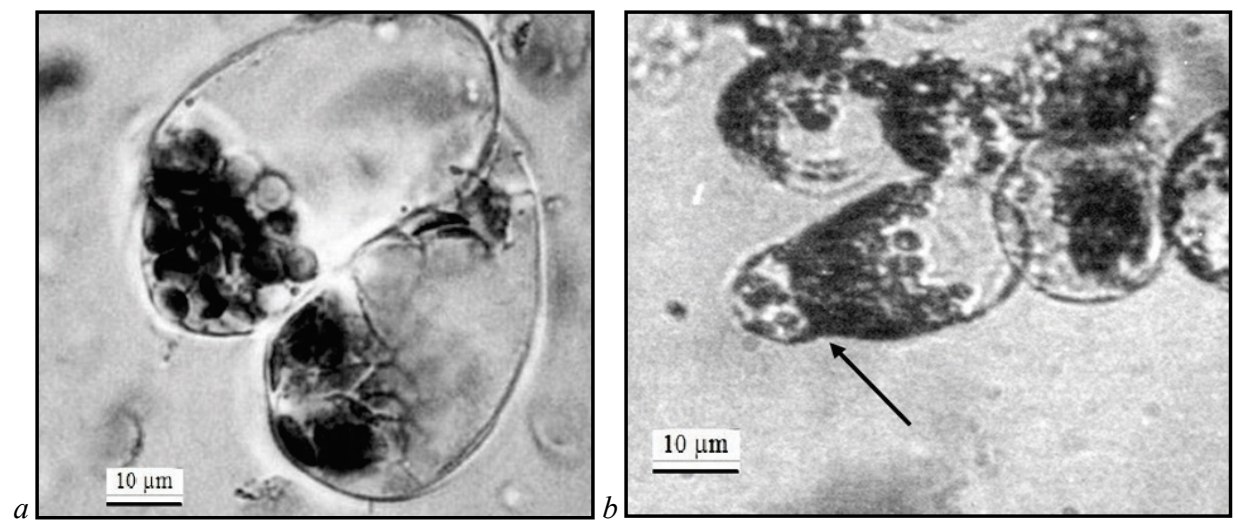

Fig. 2. Cell response to OS in the experimental variant of mesophilic protoplasts cultivation of higher plants in vitro: a - excessive cellular vacuolization and polarization of cytoplasmic elements of mitotic active cells after the stages of cell wall repair process (Nicotiana tabacum $\mathrm{L}$ ); $b$-the first asymmetrical cell division (highlighted with an arrow) with unequal cytoplasmatic elements' distribution (Arabidopsis thaliana var. colymbia (L.) Heynh.) 
Another phenotypic demonstration was observed if the introduction of gibberellin GK3 (1 mg/L) into liquid media was followed by simultaneous osmotic stress relief and reduction of NAA auxin concentration to $0.1 \mathrm{mg} / \mathrm{L}$ after the first cell division. In all the analyzed plant species under this variant of cultivation the division of the original population of mitotically active cells into two types of unequal division was observed (by the type of the first asymmetric division of the zygotic embryo in planta as well as by the type of cleavage of the mother cell into smaller daughter cells). In the experimental variant of cultivation in the selected species of higher plants the level of manifestation of the first type of unequal division was within $3.1-54.1 \%$, while the second type was within $15.0-40.6 \%$. The symmetrical divisions were $8.5-64.9 \%$ (data of the diagram in Figure 4 ).

A characteristic feature of the first type of division was an unequal distribution of cytoplasmic elements between daughter cells, among which one cell was of a large size with optically dense cytoplasm, while the second cell was of a smaller size and quite vacuolated with an optically light cytoplasm. Subsequently, there was a development of two types of microcolonies, which were formed after asymmetric cell division. One of them had a clearly expressed part consisting of compact small cells in the form of globules and long vacuolated cells, which were divided along the axis (Fig. 5). The second one represented a cone-shaped microcolony, which, as it grew, acquired forms morphologically identical to the heartshaped zygotic embryo in planta (Fig. 6). Thus, in this case there was an analogy between the first asymmetric division of somatic cells in mesophilic protoplasts culture in vitro and the first one, determined during the germinal axis, direction of zygote separation in planta, after which apical and basal cells were formed (Tvorogova \& Lutova, 2018). The second feature of the development of microcolonies with primary traits of cytodifferentiation was the determination of the symmetry axis of the second order, which was formed as a result of bilateral division of cells that had optically dense cytoplasm after the first asymmetric division (Fig. 7). The above-mentioned trajectory of microcolonies development seemed to be typical for tobacco and Arabidopsis protoplasts.

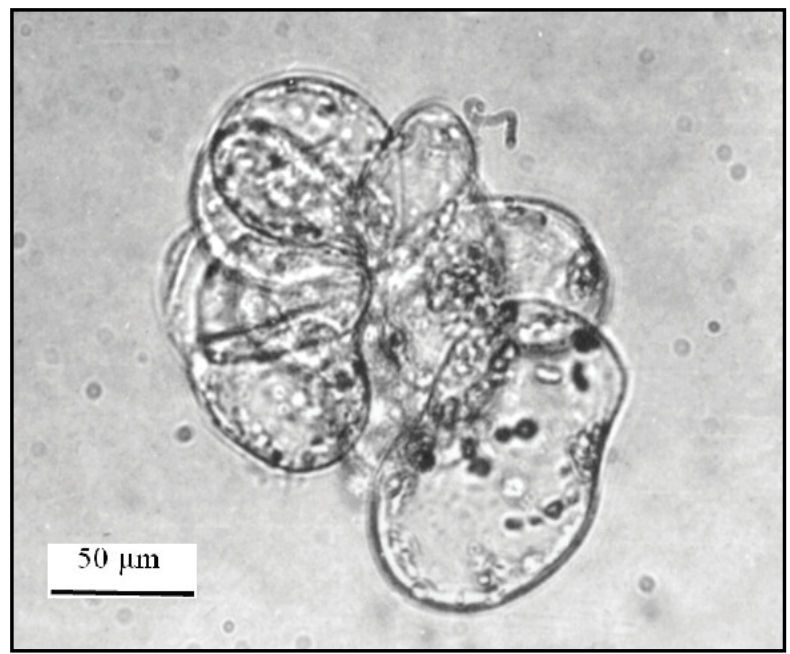

Fig. 3. Unorganized microcolony cell growth in the control variant derived from mesophilic protoplasts (Nicotiana tabacum L.)

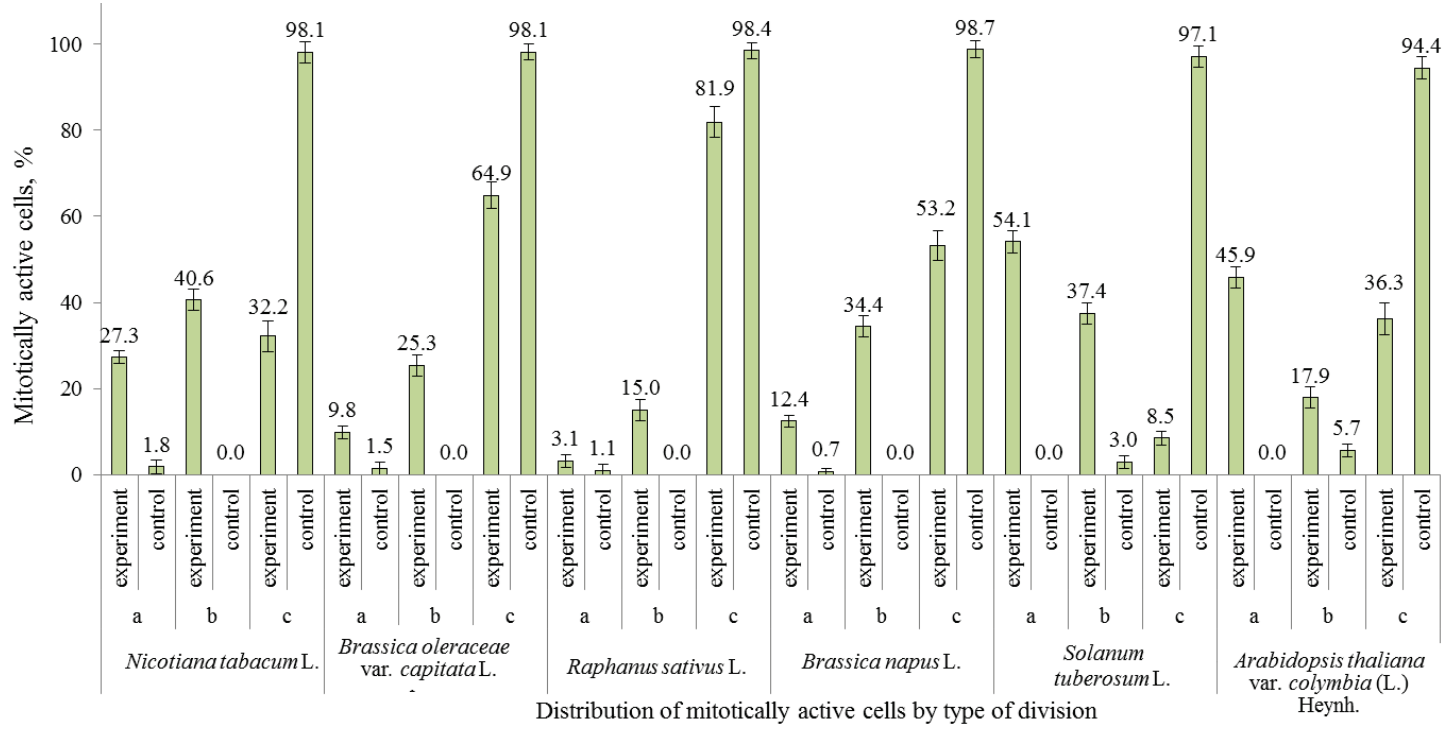

Fig. 4. Percentage ratio of different directions of division of mitotic active cells in both control and research variants in mesophilic protoplasts culture of 6 Brassicaceae and Solanaceae plant species: $a$ - the first asymmetric zygotic embryo in planta division type; $b$-division of the mother cell cleavage type into smaller daughter cells; $c$-symmetrical divisions; the numerical data in the diagram are presented as $\mathrm{x} \pm \mathrm{SD}(\mathrm{n}=5)$
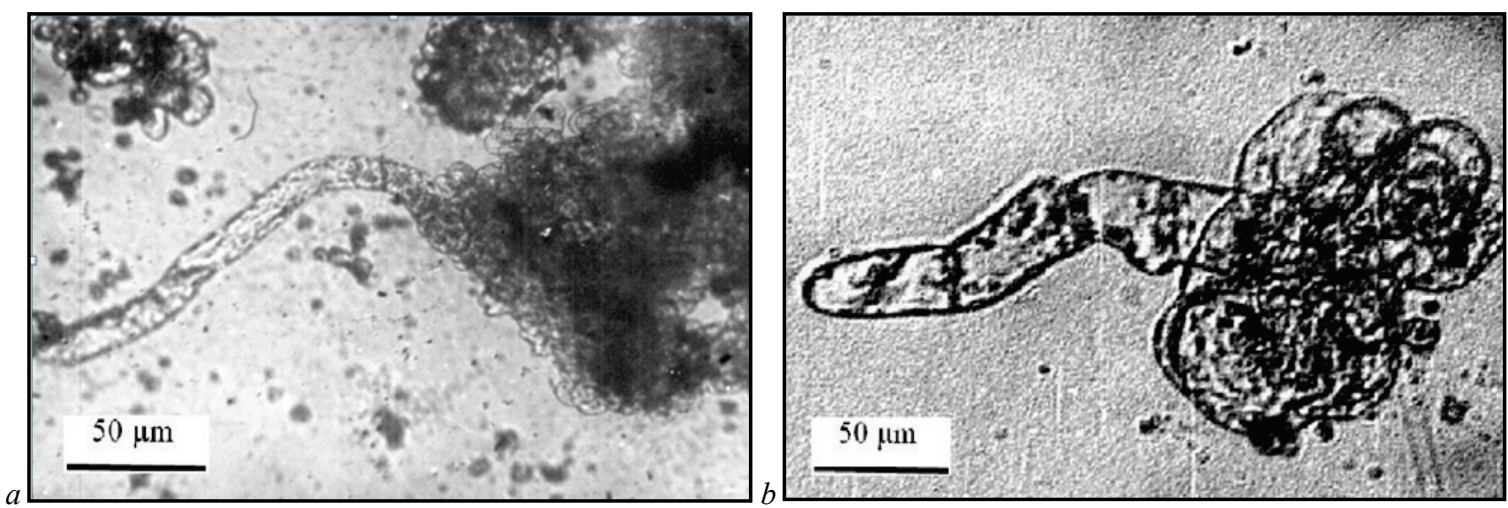

Fig. 5. Polar morphology of microcolonies in the experimental variant of the cultivated cells derived from mesophilic protoplasts: $a$ - potato of Zarevo cultivar (Solanum tuberosum L); $b$ - wild form of Arabidopsis (A. thaliana var. columbia (L.) Heynh.) 
The developmental pathway inherent mainly in rapeseed, radish, cabbage, and potato cells in the presence of gibberellin was to initiate cell division, in which the mitotically active cells were fragmented into smaller daughter cells. In this case, protoplasts, after the cell wall was repaired, were morphologically similar to somatic embryos in the heart-shaped stage of development (Fig. 8). Such cytomorphosis was observed even before the first division and only in the presence of exogenous gibberellin. During the first and subsequent mitosis, daughter cells continued to preserve the initial morphology of the mother cell, however, their cell division had no clear orientation throughout the initial axis of symmetry. Nevertheless, within the process of further development, such microcolonies held for a long time the heart-shaped form inherited from the mother cell (Fig. 8 and 9). Except for mitotic active cells, which formed microcolonies with morphological traits of structural organization in all plant species under study, there were cells that divided in an isopolar way, forming microcolonies without traits of structural organization after OS exposure and subsequent injection of exogenous gibberellin into nutrient media (Fig. 3). Consequently, in experiments with the culture of mesophilic protoplasts of higher plants in vitro it was shown that osmotic stress followed by the subsequent introduction of high doses of gibberellin GK3 into the nutrient medium led to the appearance of morphological traits of cytodifferentiation already at the initial stages of development of somatic cell microcolonies in a number of higher plants.

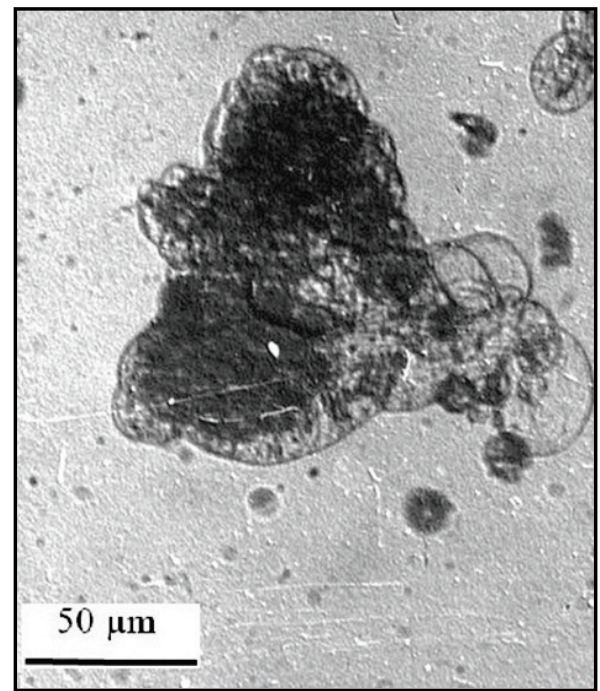

Fig. 6. Heart-shaped microcolony with morphological traits of structural organization (Nicotiana tabacum L.)

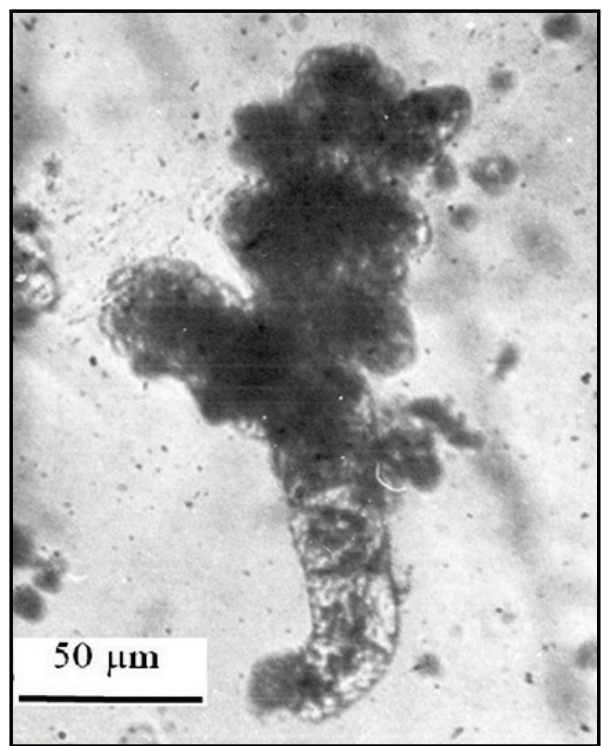

Fig. 7. Bilateral symmetry of microcolonies with morphological traits of structural organization (Arabidopsis thaliana (L.) Heynh.)

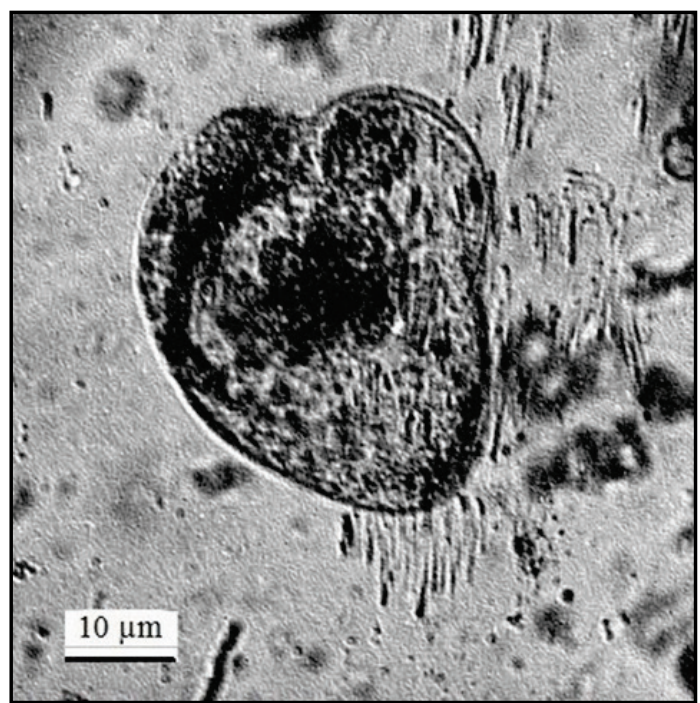

Fig. 8. Structural form of microcolonies of cells in which the mother cell has taken the morphological form of a somatic embryoid at the heartshaped stage of development even before the first division begins (Brassica napus L.)

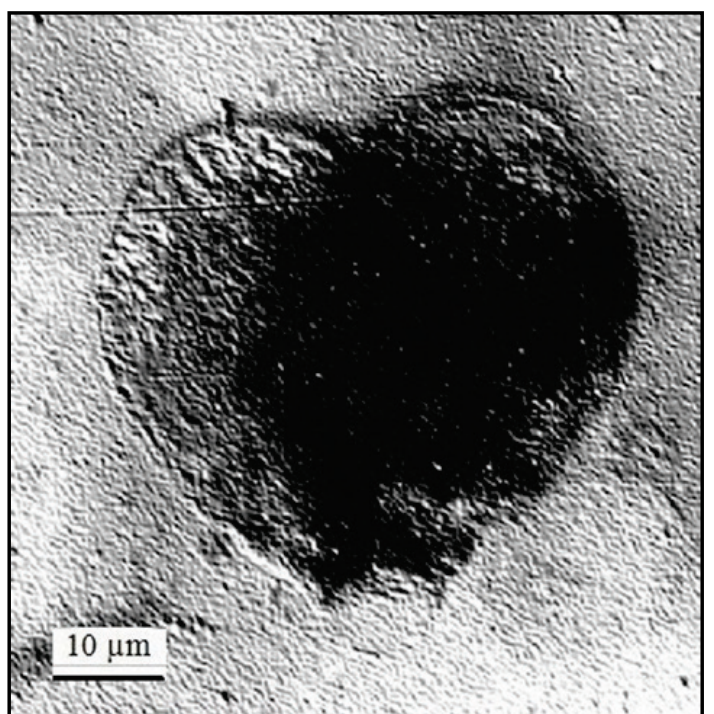

Fig. 9. Structural form of microcolonies of cells in which the mother cell has taken the morphological form of a somatic embryoid at the heartshaped stage of development even before the first division begins (Brassica oleracea var. capitata L.)

A separate study of the effect of OS on hypocotyl protoplasts of different varieties of white cabbage isolated from tissues of 7-9 day etiolated seedlings revealed one characteristic feature: the determination of cytoplasmic elements in this type of cell and the subsequent development of differential morphology of microcolonies occurred without additional injection of exogenous gibberellin (GK3) into the nutrient medium TMmod2 (k). That is, the hypocotyl protoplasts, having undergone a cell membrane repair process, morphologically resembled somatic embryos at the heart-shaped stage of development in the absence of exogenous gibberellin (cytomorphosis similar to the one presented in Figure 9 for white cabbage cells derived from mesophilic protoplasts). This fact, as well as preliminary data obtained on mesophilic protoplast culture, gave us grounds to assume that plant gibberellin has the same regulatory effect as GK3. It has been established that during the period of germination of zygote embryo, the endogenous content of different forms of gibberellin in different plant species increases by several orders of magnitude (Blume et al., 2012), which probably significantly affected the phenotypic reactions of hypocotyl protoplasts in terms of the action of osmosis. In the next series of experiments for this type of cells, the evaluation of asymmetrical division was conducted from the standpoint of phytohormonal regulation 
of proliferation and cell differentiation. Figure 10 shows the diagram reflecting the percentage ratio of different types of division of mitotic active cells in the culture of hypocotyl protoplasts of 8 varieties of white cabbage after the application of control and trial cultivation, similar to that of mesophilic protoplasts of higher plants (Fig. 4).

Evidence suggests that these cultures, in the framework of the experimental variant, were dominated by maternal cells' being divided into smaller daughter cells. The greatest number of them was registered in early-ripening cultivars: Dithmarscher Früher and Iyunskayarannyaya at $71.5-79.0 \%$ (Fig. 10). In other cultivars, this figure ranged between 25.3 $67.9 \%$. Division by type of cleavage occurred in those cells, which after OS and subsequent administration of exogenous gibberellin (GK3) acquired initial morphology with traits of structural organization (heart-shaped one). In late ripening varieties of white cabbage, the highest percentage of such cells (more than 50\%) was observed in Kharkivska zymnia, Lika, Lesya and Bilosnizhka cultivars (Fig. 10).

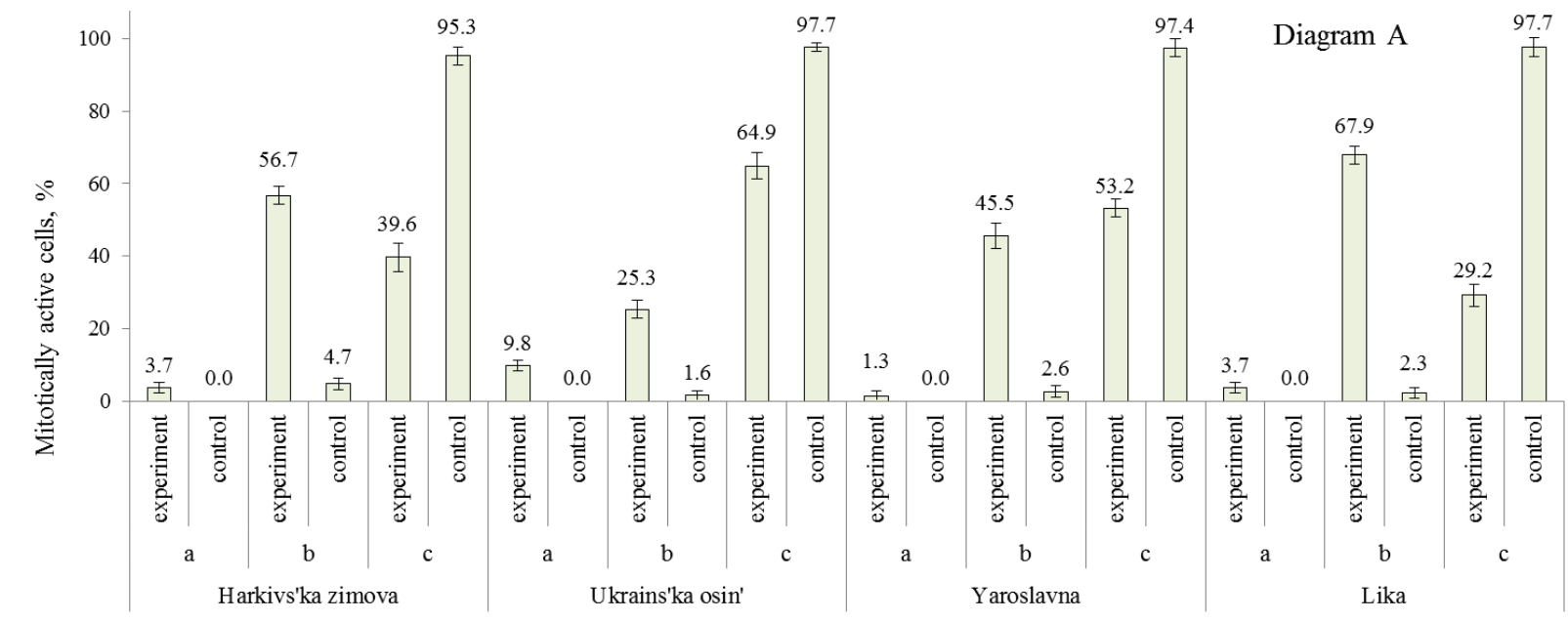

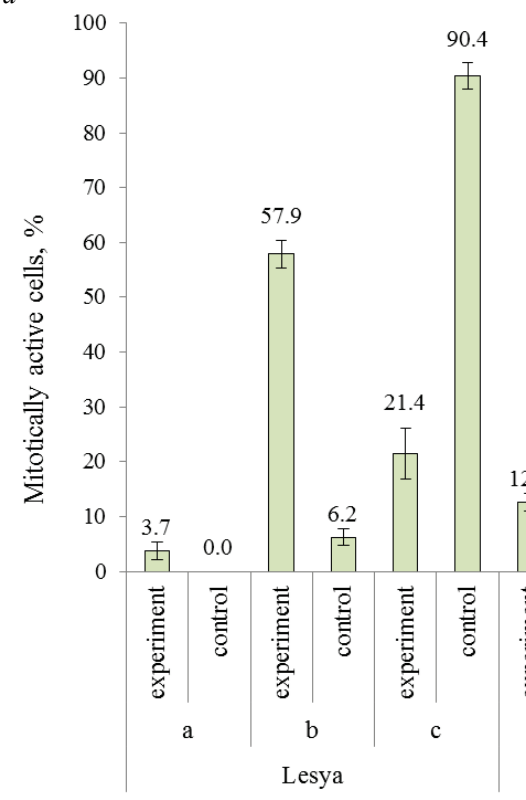

$b$

Distribution of mitotically active cells by type of division

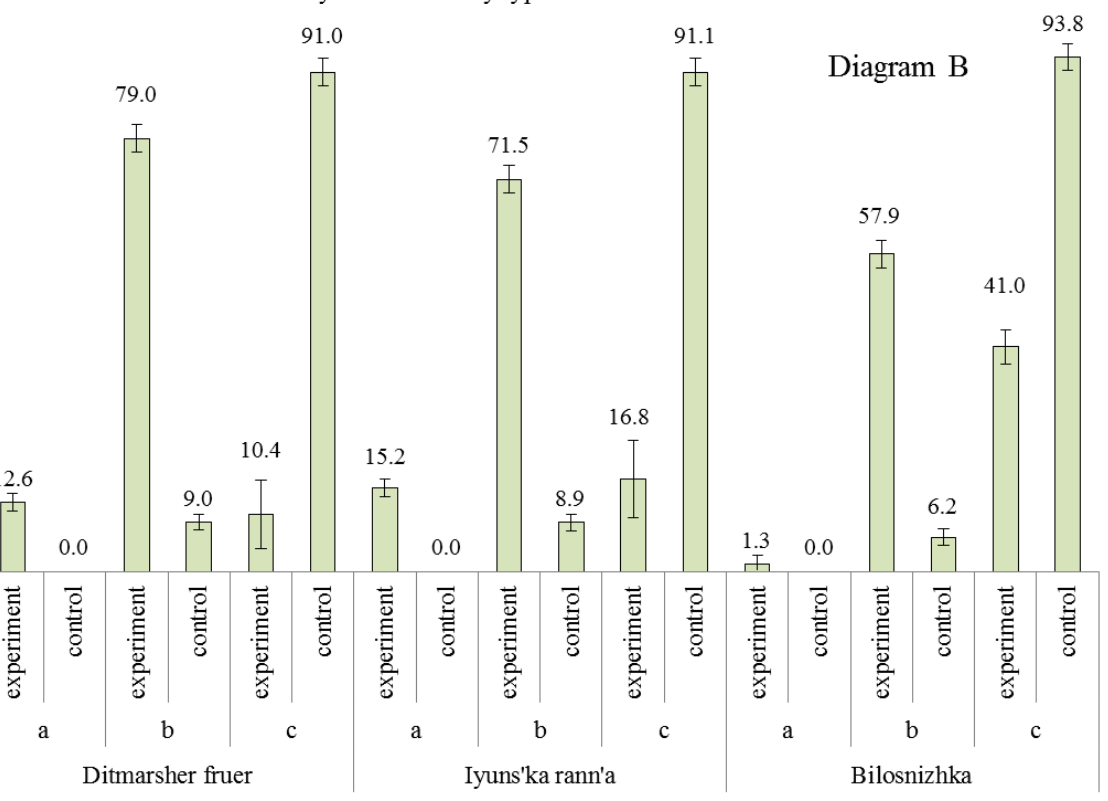

Distribution of mitotically active cells by type of division

Fig. 10. The percentage ratio of different types of division of mitotic active cells in both control and research variants in culture of hypocotyl protoplasts in vitro of white cabbage cultivars (Brassica oleraceae var. capitata L.): $a$ - the first asymmetric zygotic embryo in planta division type; $b$ - division of the mother cell cleavage type into smaller daughter cells; $c-$ symmetrical divisions; the numerical data in the diagrams are presented as $\mathrm{x} \pm \mathrm{SD}(\mathrm{n}=5)$

It is common practice when at the stage of their cultivation up to the nutrient media TMmod3(d) is applied, they continued to preserve the differential morphology. To support mitosis, the culture was transferred to the optimal growth medium for microcolonies TMmod3 (d) with modified content of growth regulators $(1 \mathrm{mg} / \mathrm{L} \mathrm{BAP}, 1 \mathrm{mg} / \mathrm{L} \mathrm{GK} 3,0.2 \mathrm{mg} / \mathrm{L}$ 2.4-D and $0.1 \mathrm{mg} / \mathrm{L}$ NAA), glucose $(0.4 \mathrm{M})$ as well. In the process of further cultivation, microcolony growth was followed by a gradual loss of differential morphology and a transition to unorganized growth. Moreover, the further presence of gibberellin $(1 \mathrm{mg} / \mathrm{L} \mathrm{GK} 3)$ in the growth regulators of TMmod3 (d) nutrient medium had a negative impact on cell development, increasing their transition to growth by extending while reducing mitotic activity. This affected the change in the qualitative composition of cell populations, in which not meristematic, but vacuolated parenchymal cells began to predominate in an amount up to $65-70 \%$ of the total population (Fig. 12). The dynamics of mitotic activity of cells, which took place during the 2-month period of cell cultivation with the use of different options of osmotic and hormonal regulation of plant cell culture growth, derived from hypocotyl protoplasts of white cabbage, is reflected in the graph in Figure 13. The obtained results show that the value of mitotic index reliably differs in the two experimental variants of cell cultivation with the presence and absence of GK3 in the composition of growth regulators of TMmod2 (e) nutrient medium. Moreover, the value of this statistical indicator was higher in the options of cultivation, where gibberellic acid was not used. Cell proliferation in the presence of the auxin regulator 2,4-D in the control variant of cultivation affected the maximum number of peaks of mitotic activity of cells. Altogether, the obtained results indicate that changes in osmotic and hormone regulation had a peculiar effect on growth processes in cultivated plant cells. 

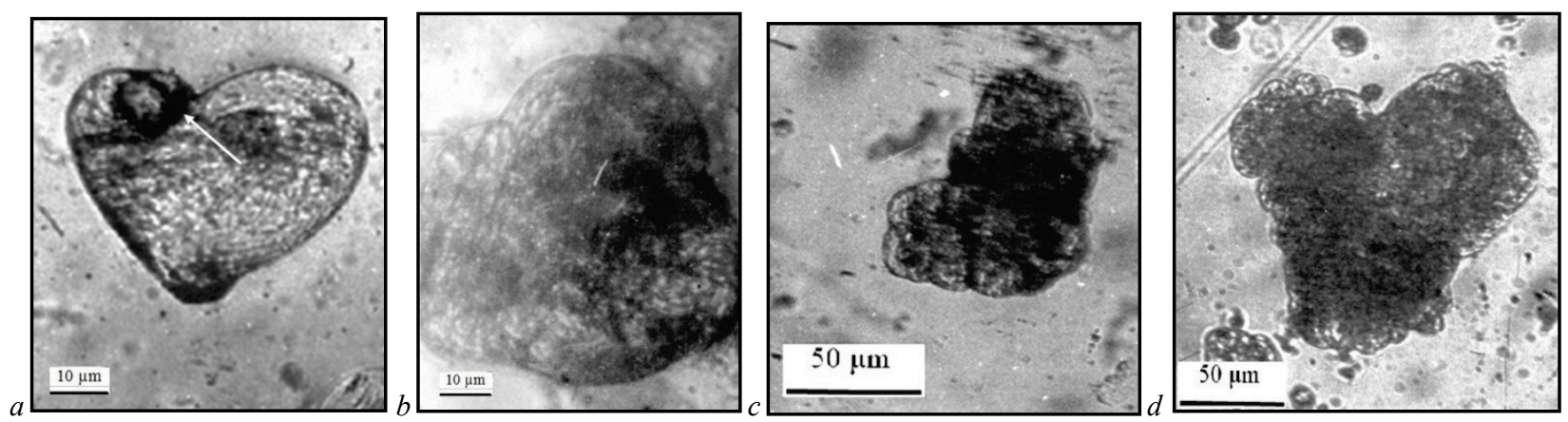

Fig. 11. Typical microcolony development with morphological traits of structural organization in hypocotyl protoplasts' in vitro culture of white cabbage Kharkivska zymnia, Ukrainska osin, Yaroslavna, Lika, Lesia, Bilosnizhka, Dithmarscher Früher and Iyunskarannia (Brassica oleraceae var. capitata L.): $a$ - the first cell division (indicated by an arrow), which initiates the onset of division of a more vacuolated mother cell into smaller daughter cells;

$b$ - growth of microcolonies of cells after their transfer to the nutrient medium TMmod3(d); $c, d$-gradual transition to unorganized microcolony growth with primary traits of structural organization on the TMmod3(d) nutrient medium

Decrease in mitotic cell activity in the framework of variants with the use of gibberellic acid correlates well with the beginning of cell growth by extension and inhibition of cell division. By the number of mitotic active cells, the research variant of cultivation with application of hypotonic stress only took an intermediate place between the control and experimental variants with application of a high dose of gibberellin in the TMmod3(e) nutrient medium. This intermediate state was preserved up to about 20 days of cultivation, and the mitotic index value was almost equal to the control one (Fig. 13).

\section{Discussion}

Characterizing the effect of growth regulators of nutrient media on the development of microcolonies of cells, we should note the generality of our results obtained in earlier studies of regulatory action of phytohormones at the in planta level. Cells in higher plants are known to lack mobility due to the presence of cell walls, so plant morphogenesis is largely dependent on regulated cell division in a strictly defined direction (Medvedev, 1996). Accurate determination of the cell division area is extremely important for many forming processes, with the structural components of cell cytoskeleton playing an important role in this process, among which microtubes (MT) perform the most important function (Medvedev, 1996). The first indication that the cell begins to divide in this direction appears immediately after interphase, as the MTs reorient in the process of preparing for mitosis. There is evidence that processing with auxin leads to transverse (relative to the long axis) orientation of MT in cells of higher plants (Blume et al., 2012). It was found out that the impact of the auxin on the orientation of MT is after the preliminary processing of the GK3 (Blume et al., 2012). Gibberellins, like auxin, induce transverse (relatively long axis) location of MT cells (Blume et al., 2012). Short-term cell extension under the influence of gibberellin is not followed by MT retargeting. GK3 pre-treatment leads to MT reorientation if the gibberellin combines with auxin. Data from other studies show that the orientation of MT also depends on the cytokinins. It has been determined that action of kinetin on plant cells can change the location of these structural components of cytoskeleton from transverse to longitudinal (Blume et al., 2012). Thus, under the influence of phytohormones there is a dynamic modification of cortical MT system in mitotic active cells in planta. In the presence of all the above-mentioned phytohormone analogs in the nutrient medium for the cultivation of white cabbage protoplasts, we observed similar phenomena in the growth of cell clones. However, the induction of differential cell division required a balanced selection of growth regulators as well as their coordinated application in time together with the regulation of osmotic pressure in the nutrient medium.

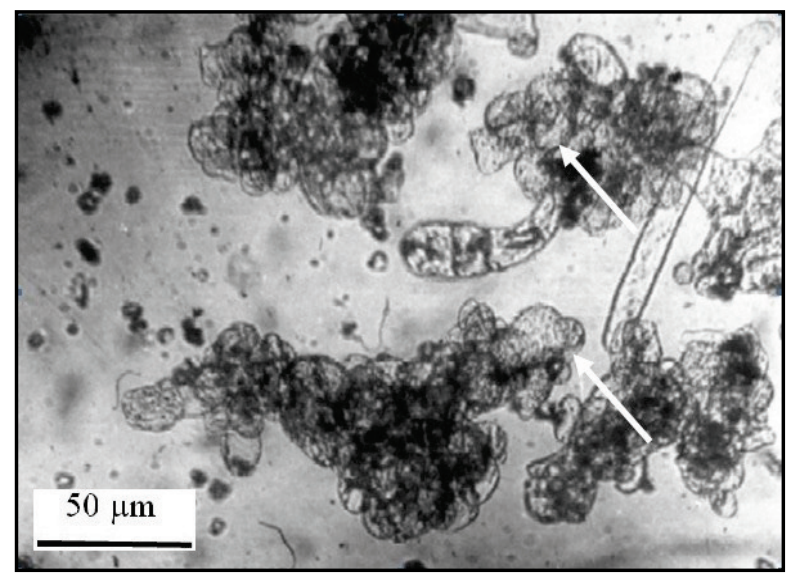

Fig. 12. Transition to cell growth by stretching (indicated by arrows) in microcolony in the TMmod3(d) nutrient medium (culture of hypocotyl protoplasts in vitro of white cabbage of Kharkivska zymnia cultivar)

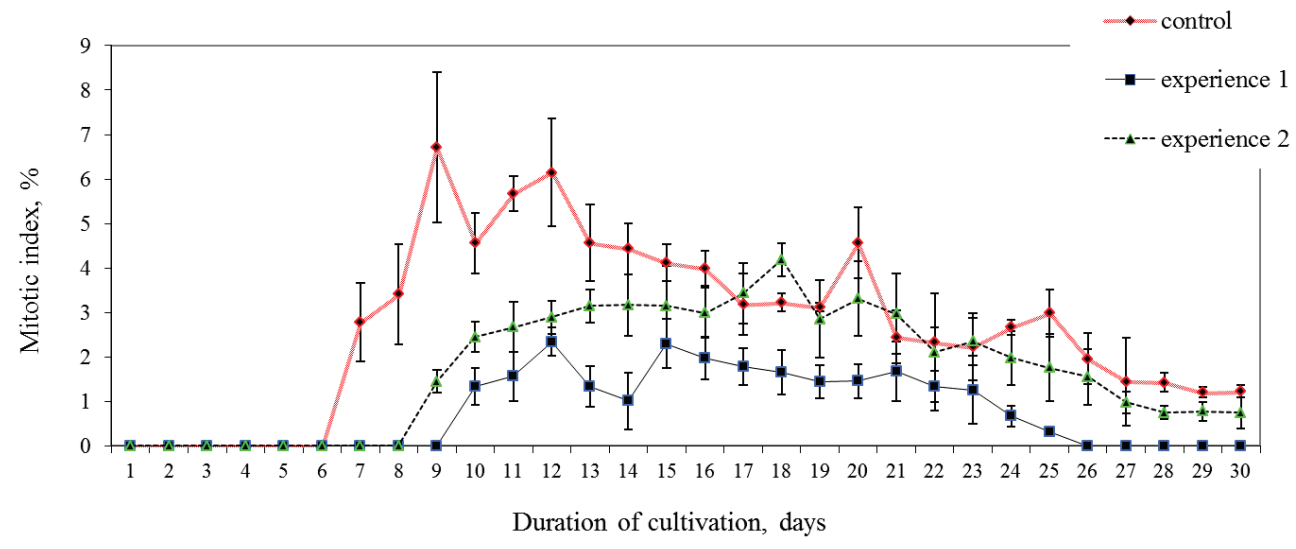

Fig. 13. Features of the mitotic cell activity identified at different variants of cultivation of hypocotyl protoplasts (averaged data for 8 varieties of white head cabbage): experiment 1 - cultivation mode with osmotic stress and subsequent introduction of gibberellin GK3 into nutrient medium; experiment 2 - osmotic stress-only cultivation mode; the numerical data in the graph are presented as $x \pm \operatorname{SD}(n=5)$ 
Assessing the contribution of osmotic stress to cytodifferentiation processes, it should be noted that previously various types of stress agents were widely used in vitro culture for embryogenesis induction. For example, cold and osmotic stresses are often used for androgenesis induction in the cultivation of isolated microspores (Ochattet al., 2009; Islam \& Tuteja, 2012). The addition of abscisic acid (AA) to nutrients as one of the stress agents has been applied to induce cytodifferentiation in carrot globular embryos (Jameel \& Abdulaziz, 2012). In our case, one of the possible mechanisms of osmotic stress influence is the emerging of a powerful diffuse gradient, which led to the intake of excess water and growth regulators (primarily auxin) into the cells. Forceful hydration of both membrane and cytoplasmic proteins could also contribute to the "unblocking" of the functional activity of a number of enzyme systems as well as to the mobilization of the genome of cells as a whole (Komaki \& Sugimoto, 2012). It is worth noting that when using a system of isolated protoplasts, the heterogeneity of the original cell population is determined by the absence of synchronization in the phases of the cell cycle. Thus, within the framework of our researches we observed a different ratio of cell population being developed by cytodifferentiation. The morphology of the microcolonies obtained in the result of our study was common with the early stages of development of protoplasts of both Gentiana kurroo (Niedziela \& Rybczyński, 2007) and G. straminea (Shi et al., 2016), which developed through direct somatic embryogenesis in specially selected plant lines in the deficiency of exogenous gibberellin. Related morphology has been observed, also in the initial division of the zygote in planta (Zhao \& Sun, 2015) as well as polarization (formation by root-like projection) in the brown algae (Bogaert et al., 2013). As already proven, in the lower algae, such polarization is due to the polar transport of auxin. In terms of our research, the morphological diversity of microcolonies according to the differential types may be explained by the accelerated intermutation of various gibberellins by cell enzyme systems (Hedden \& Sponsel, 2015), while the determinacy of symmetry axes - by the effect of GK 3 on the orientation of cytoplasm microtubes of mitotic active cells in a certain direction, e.g. along the axis of growing microcolonies (Wenzel et al., 2000). It is worth highlighting that gibberellin GK3 is rarely used in plant culture in vitro, while more often at the last stage of regeneration (Edwin et al., 2007) and is almost out of use in cultivated media at early stages of protoplast culture development. Assessing the possible role of gibberellin in cytodifferentiation processes, it should be noted that plants have predominantly the same type of auxin (IAA) and cytokinin (zeatine), but more than 130 different forms of gibberellin, most of which exhibit their activity specifically and only at specific stages of plant development (Binenbaum et al., 2018). Besides, gibberellin synthesis level in planta increases significantly in the process of de novo formation of all organs of higher plants and, especially, in the development of the zygotic embryo, which is quite convincingly demonstrated in embryological studies on rape (Hays et al., 2001). Nevertheless, studies of the phytohormone content in the unorganized growth of tobacco callus revealed a complete absence of endogenous gibberellins (Nawaga et al., 1987). Our results show that gibberellins directly participate in regulation of somatic cell differential division. Based on the above, there is every ground to assume that of all phytohormones, it is the gibberellin that is the hormone determinant of morphogenetic processes in plants. To verify the current hypothesis, we require more detailed studies and clarifications of the regulatory functions of this phytohormone in plants. Our morphological evaluation of microcolonies that underwent the OS stage provides additional evidence in favour of the hypothesis, since even the presence of only one compound from the class of gibberellins (GK3) in the hormonal composition of the nutrient medium led to the formation of microcolonies with initial morphological traits of structural organization. The generality of reaction on presence of gibberellin in mesophilic protoplasts of the species under study gives the grounds to assume that the phenomenon described by us represents the general physiological regularity inherent in higher plants as a whole. Summing up the effect of GK3 gibberellin at the early stages of development of hypocotyl protoplasts of different varieties of white cabbage genotypes, it ought to be remarked that the effect of this phytohormone is more negative than positive. According to Butenko (1981), when growing an explant plant tissue in the dark-room conditions with the use of gibberellic acid, it is possible to suppress the function of auxin oxidase, which may adversely affect the mitotic activity of cells due to the growth of endogenous auxin. Since under conditions of optimal proliferation of cells, their cultivation during the first 20 days was carried out in the dark-room conditions, the above-mentioned negative impact of this phytohormone on the mitotic activity of cells could naturally occur.

The generalization of the factors that influenced the asymmetric division of cells derived from mesophilic and hypocotyl protoplasts of higher plants is presented in Table 2. The table shows in more detail the main types of asymmetric cell division of the studied plant species, depending on the time-coordinated factors of the osmotic and hormonal regulation of the division process. At the stage of the sixth mitosis in dividing cells, microcolonies switched to unorganized growth, while losing morphological traits of structural organization. In our opinion, the reason for such a transition to the unorganized growth of microcolonies is the incorrect choice and balance of growth regulators in the composition of nutrient media TMmod3 (e) and SWmod3 (e). The possibility of implementing a program of somatic embryogenesis in protoplast culture in vitro for the studied plant species requires additional study of the factors of cell differentiation.

As is known, isolated protoplast is the most disintegrated structure of the plant body. Therefore, this cell type is an ideal experimental object for studying the regularities of the "cell-plant" development cycle when simulating morphogenetic processes in vitro culture. Currently, significant progress has been made in studying plant protoplasts, but the issue of their cultivation and regeneration of plants on their basis is still of fundamental importance. This is mainly due to the fact that the protoplast is a component of a complex system of development, and in addition, generally, it is subject to key stress factors when cultivated. It is known that different types of stress can influence the regulation of genes through their expression or derepression. According to Cocking (1972), the protoplast is a damaged, with a missing cellular shell, isolated plant cell, which is under osmotic stress. The principal physiological feature of protoplasts is the ability, under certain conditions of cultivation, to regenerate the cellular cover and begin to divide, forming cell colonies or even plants (Davey et al., 2005). Having undergone cellular repair process, plant cells are formed in the same way as in a conventional suspension culture (Sidorov et al., 1985), therefore the conditions of their cultivation are subject to change. It is required as follows: reduction of osmotically active concentration in substances, gradual change of hormonal balance being dominated by cytokinins. Existing experimental practice requires an empirical selection of all three cultivation regulatory factors (Sidorov et al., 1985), thus a certain number of protoplast nutrient media options have been developed that have been applied to a limited number of genotypes or plant cultivars. Violation of any of the above-mentioned elements of the regulation of cultural growth as well as development leads, commonly, to cell death. A special role in maintaining cell growth and differentiation in protoplast culture belongs to the regulators auxin, among which we should mention the special role of 2,4-D as an activator of reprogramming the genome of special somatic cells, after which they become totipotent and achieve their development potential, just as it occurs in egg cells after fertilization (Peterson et al., 2016).

In our study, the occurrence of the regulator 2,4-D was obligatory as in its absence cultivated cells of plants did not restore or completely lost their mitotic activity. It has been established that the regulator belongs to the class of phytohormonal herbicides, a quite toxic substance, which negatively affects the ontogenesis of plants. This has been proven in numerous studies on many plant species (Song, 2014). In particular, the toxicity of this substance is manifested in chromosomal disorders and the growth of meristematic cells in apical zones (Song, 2014). 2,4-D is poorly disposed of by plants. It provides grounds to assume that while implementing the program of plant morphogenesis in vitro, the regulator may disrupt regeneration processes in the cultivated objects due to the herbicidal effect, especially in the determination of stem organogenesis in dicotyledonous plants.

Thus, the question of the final determination of the principles of osmotic, trophic and hormonal regulation of morphogenesis in vitro of higher plant protoplasts requires further study. The identified common consistent pattern of the development of somatic cells an early stage of the growth of protoplast culture of higher plants in vitro served as a basis for the authors' developed method of the effective plant regeneration in protoplast in vitro culture of white cabbage through organogenesis. The results of these studies are planned to be presented by us in the next article. 
Table 2

Exogenous factors of plant cell cultivation before and after cell wall repair that influenced the asymmetric cell division in the culture of mesophilic and hypocotyl protoplasts of six plant species of the Brassicaceae and Solanaceae families

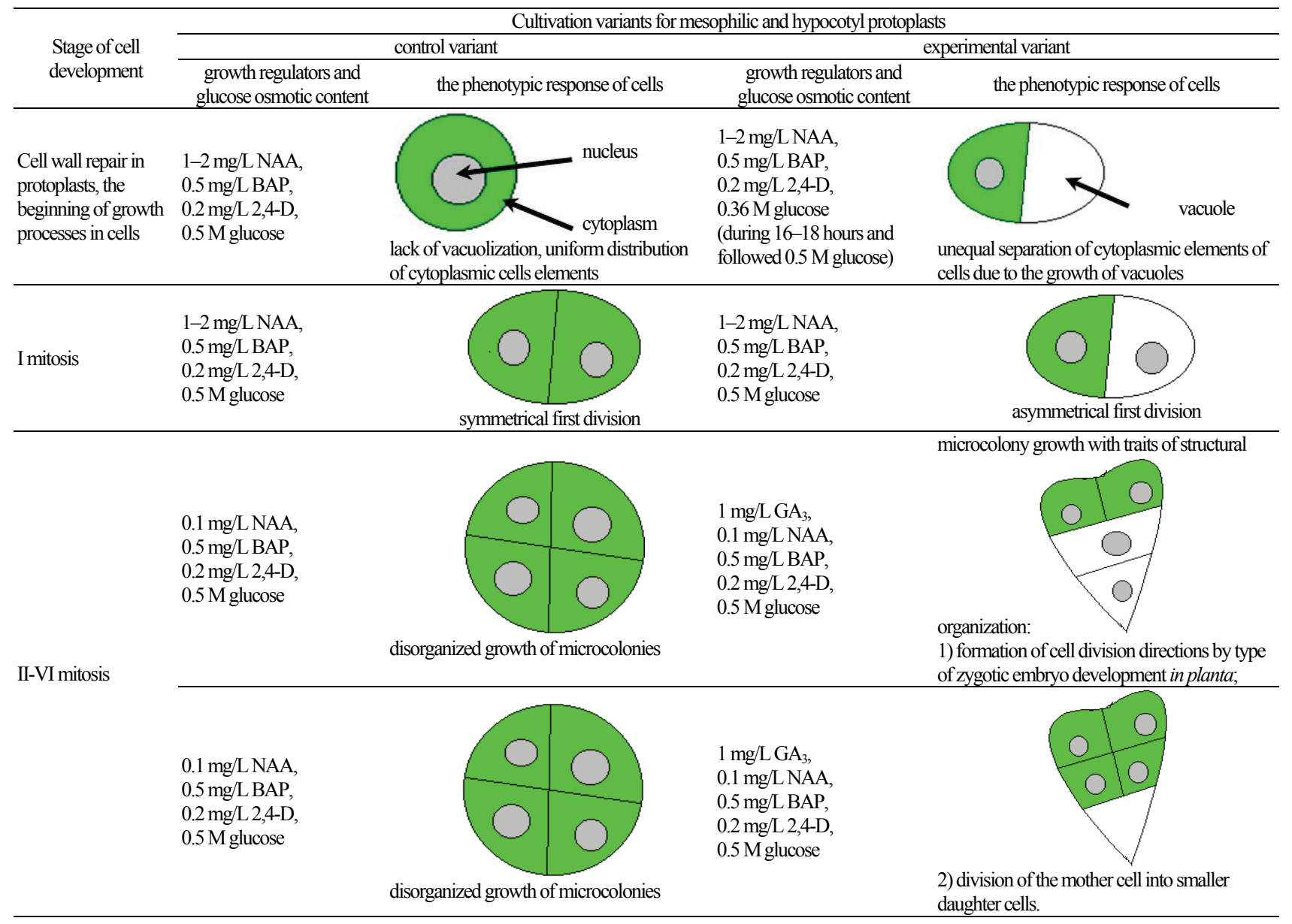

\section{Conclusion}

The key result of the research carried out is the determination of the development process for the cultivation of protoplast of higher plants that provide for an indication of the process of asymmetric cell division in vitro. Exogenous gibberellin has been proved to be one of the initiators of such a division type. As has been shown above, this class of phytohormones significantly influences the initiation of morphogenetic processes in higher plants, therefore, in our experiments, the action of gibberellic acid (GK3) has been studied in more detail at the initial stage of cultivation of mesophilic protoplasts of six species of plant belonging to the Brassicaceae and Solanaceae families.

In experiments with mesophilic protoplasts it was shown that shortterm osmotic stress within 16-18 hours in combination with the subsequent administration of high doses of gibberellin GK3 into the nutrient medium led to the appearance of morphological traits of cytodifferentiation already at the initial stages of cell microcolonies in a number of higher plants. At the same time in all analyzed plant species there was observed the division of the original population of mitotic active cells into two types of asymmetric division: by the type of cleavage of the mother cell into smaller daughter cells and by the type of the first asymmetric division of the zygotic embryo in planta. A special study of the effect of osmotic stress on hypocotyl protoplasts of various cultivars of white cabbage, isolated from hypocotyl 7-9 day etiolated seedlings, revealed a rather characteristic feature: the determination of cytoplasmic elements in this type of cells and the subsequent development of differential morphology of microcolonies occurred without additional injection of exogenous gibberellin (GK3) into the nutrient medium. This fact, as well as the data obtained on mesophilic protoplasts, gave us grounds to assume that phytogenic gibberellin, localized in juvenile etiolated seedlings, which were the source of protoplasts, had a regulatory effect similar to that of GK3.

\section{References}

Besson, S., \& Dumais, J. (2011). Universal rule for the symmetric division of plant cells. Proceedings of the National Academy of Sciences of the United States of America, 108(15), 6294-6299.

Binenbaum, J., Weinstain, R., \& Shani, E. (2018). Gibberellin localization and transport in plants. Trends in Plant Scitnce, 23(5), 410-421.

Blume, Y. B., Krasylenko, Y. A., \& Yemets, A. I. (2012). Effects of phytohormones on the cytoskeleton of the plant cell. Russian Journal of Plant Physiology, 59(4), 515-529.

Bogaert, K. A., Arun, A., Coelho, S. M., \& De Clerck, O. (2013). Brown algae as a model for plant organogenesis. Methods in Molecular Biology, 959, 97-125.

Butenko, R. G. (1981). Izolirovannye protoplasty rastenij - ob'ekt i model' dlja fiziolog-icheskih issledovanij: Kul'tura kletok rastenij [Isolated plant protoplasts as the object and model of physiological studies: Plant cell culture]. Nauka, Moscow. Pp. 69-84 (in Russian).

Capron, A., Chatfield, S., Provart, N., \& Berleth, T. (2009). Embryogenesis: pattern formation from a single cell. The Arabidopsis Book, 7, e0126.

Cocking, E. C. (1972). Plant cell protoplasts-isolation and development. Annual Review of Plant Physiology, 23, 29-50.

Dante, R. A., Larkins, B. A., \& Sabelli, P. A. (2014). Cell cycle control and seed development. Frontiers in Plant Science, 5, 493.

Davey, M. R., Anthony, P., Power, J. B., \& Lowe, K. C. (2005). Plant protoplasts: Status and biotechnological perspectives. Biotechnology Advances, 23(2), 131-171.

Edwin, G., Hall, M., \& De Klerk, G.-J. (2007). Plant growth regulators III: Gibberellins, ethylene, abscisic acid, their analogues and inhibitors; miscellaneous compounds. In: Edwin, M. A. J., \& George, F. (Eds.). Plant propagation by tissue culture. 3rd Edition. Springer. Pp. 22.

Errera, L. (1888). Über zellformen und siefenblasen. Bottanisches Centralblatt, 34, 395-399.

Flindt, R. (1992). Biologija v cifrah [Biology in numbers]. Mir, Moscow (in Russian).

Hays, D., Mandel, R., \& Pharis, R. (2001). Hormones in zygotic and microspore embryos of Brassica napus. Plant Growth Regulation, 35, 47-58.

Hedden, P., \& Sponsel, V. (2015). A century of gibberellin research. Journal of Plant Growth Regulation, 34(4), 740-760. 
Herth, W., \& Schnepf, E. (1980). The fluorochrome. Calcofluor white binds oriented to structural polysaccharide fibrilis. Protoplasma, 105, 129-133.

Horvitz, H. R., \& Herskowitz, I. (1992). Mechanisms of asymmetric cell division: Two Bs or not two Bs, that is the question. Cell, 68, 237-255.

Islam, S. M., \& Tuteja, N. (2012). Enhancement of androgenesis by abiotic stress and other pretreatments in major crop species. Plant Science, 182, 134-144.

Jameel, M., \& Abdulaziz, M. (2012). Effect of abscisic acid and polyethylene glycol on the synchronization of somatic embryo development in date palm (Phoenix dactylifera L.). Biotechnology, 11,318-325.

Komaki, S., \& Sugimoto, K. (2012). Control of the plant cell cycle by developmental and environmental cues. Plant and Cell Physiology, 53(6), 953-964.

Kuchuk, N. V. (2017). Cell genetic engineering: Transmission genetics of plants. Cytology and Genetics, 51, 103-107.

Laux, T., Würschum, T., \& Breuninger, H. (2004). Genetic regulation of embryonic pattern formation. Plant Cell, 16, 190-202.

Maliga, P., Sz. Breznovits, Á., \& Márton, L. (1973). Streptomycin-resistant plants from callus culture of haploid tobacco. Nature New Biology, 244, 29-30.

Mansfield, S. G., \& Briarty, L. G. (1991). Early embryogenesis in Arabidopsis thaliana. II. The developing embryo. Canadian Journal of Botany, 69(3), 461-476.

Medgyesy, P., Menczel, L., \& Maliga, P. (1980). The use of cytoplasmic streptomycin resistance: Chloroplast transfer from Nicotiana tabacum into Nicotiana sylvestris, and isolation of their somatic hybrids. Molecular Genetics and Genomics, 179(3), 693-698.

Medvedev, S. S. (1996). Fiziologicheskie osnovy poljarnosti u rastenij [Physiological basis of polarity in plants]. Kol'na, Saint Petersburg (in Russian).

Minc, N., \& Piel, M. (2012). Predicting division plane position and orientation. Trends in Cell Biology, 22, 193-200.

Moukhtar, J., Trubuil, A., Belcram, K., Legland, D., Khadir, Z., Urbain, A., Palauqui, J.-C., \& Andrey, P. (2019). Cell geometry determines symmetric and asymmetric division plane selection in Arabidopsis early embryos. PLoS Computational Biology, 15(2), e1006771.

Murashige, T., \& Skoog, F. (1962). A revised medium for rapid growth and bioassays with tobacco tissue cultures. Physiology of Plant, 15(2), 473-497.

Nakagawa, S., Tjokrokusumo, D. S., Sakurai, A., Yamaguchi, I., Takahashi, N., $\&$ Syono, K. (1987). Endogenous levels of gibberelins, IAA and cytokinins in tobacco crown gall tissues of different morphologies. Plant Cell Physiology, 28, 485-493.

Niedziela, A., \& Rybczyński, J. (2007). The effect of several factors on somatic embryogenesis and plant regeneration in protoplast cultures of Gentiana kurroo (Royle). Plant Cell, Tissue and Organ Culture, 91, 263-271.

Ochatt, S., Pech, C., Grewal, R., Conreux, C., Lulsdorf, M., \& Jacas, L. (2009). Abiotic stress enhances androgenesis from isolated microspores of some legume species (Fabaceae). Journal of Plant Physiology, 166(12), 1314-1328.
Palovaara, J., de Zeeuw, T., \& Weijers, D. (2016). Tissue and organ initiation in the plant embryo: A first time for everything. Annual Review of Cell and Developmental Biology, 32, 47-75.

Peterson, M. A., McMaster, S. A., Riechers, D. E., \& Skelton, J. (2016). 2,4-D past, present, and future: A review. Weed Technology, 30(2), 303-345.

Polevoj, V. V. (1982). Fitogormony [Phytohormones]. Leningradskiy Gosudarstvenniy Universitet, Leningrad (in Russian).

Polevoj, V. V., \& Salamatova, T. S. (1991). Fiziologija rosta i razvitija rastenij [Physiology of plant growth and development]. Leningradskiy Gosudarstvenniy Universitet, Leningrad (in Russian).

Rasmussen, C. G., Humphries, J. A., \& Smith, L. G. (2011). Determination of symmetric and asymmetric division planes in plant cells. Annual Review of Plant Biology, 62, 387-409.

Roeder, A. H. K. (2012). When and where plant cells divide: A perspective from computa-tional modeling. Current Opinion in Plant Biology, 15(6), 638-644.

Shi, G., Yang, L., \& He, T. (2016). Plant regeneration from protoplasts of Gentiana straminea Maxim. Open Life Sciences, 11(1), 55-60.

Sidorov, V. A., Piven, N. M., Gleba, Y. Y., \& Sytnik, K. M. (1985). Somaticheskaya gibridi-zatsiya paslenovykh [Solanaceae somatic hybridization]. Naukova Dumka, Kiev (in Russian).

Smolarkiewicz, M., \& Dhonukshe, P. (2013). Formative cell divisions: Principal determinants of plant morphogenesis. Plant and Cell Physiology, 54, 333-342.

Song, Y. (2014). Insight into the mode of action of 2,4-dichlorophenoxyacetic acid (2,4-D) as an herbicide. Journal of Integrative Plant Biology, 56(2), 106-113.

Sukhoverov, V. S., \& Romanov, G. A. (2010). Modeling hormone controlled bipolar growth in cell structures of plants type. Autom Remote Control, 71, 1184-1195.

Tvorogova, V. E., \& Lutova, L. A. (2018). Genetic regulation of zygotic embryogenesis in angiosperm plants. Russian Journal of Plant Physiology, 65(1), 1-14.

Wenzel, C., Williamson, R., \& Wasteneys, G. (2000). Gibberellin-induced changes in growth anisotropy precede gibberellin-dependent changes in cortical microtubule orientation in developing epidermal cells of barley leaves. Kinematic and cytological studies on a gibberellin-responsive dwarf mutant, M489. Plant Physiology, 124(2), 813-822.

Yoshida, S., Barbier de Reuille, P., Lane, B., Bassel, G. W., Prusinkiewicz, P., Smith, R. S., \& Weijers, D. (2014). Genetic control of plant development by overriding a geometric division rule. Developmental Cell, 29(1), 75-87.

Zhao, P., \& Sun, M.-X. (2015). The maternal-to-zygotic transition in higher plants: available approaches, critical limitations, and technical requirements. In: Lipshitz, H. D. (Ed.). Current topics in developmental biology. Academic Press. Vol. 113. Pp. 373-398. 